Pranav Mazumdar, J N Chakraborty

Dr. B R Ambedkar National Institute of Technology, Department of Textile Technology, Jalandhar 144011, Punjab, India

\title{
Dyeing of Cotton with Indigo Using Alkaline Protease and Additives
}

\author{
Barvanje bombaža z indigom z uporabo alkalne proteaze in \\ aditivov
}

\author{
Original Scientific Article/Izvirni znanstveni članek
}

Received/Prispelo 03-2019 • Accepted/Sprejeto 08-2019

\begin{abstract}
Indigo is invariably applied on cotton to produce an attractive blue shade, together with the desired wash-down effects. Because it is water insoluble, indigo is reduced and solubilised with sodium dithionite and $\mathrm{NaOH}$ to develop affinity for cotton. Sodium dithionite dissociates into hazardous by-products viz. sulphate, sulphite and thiosulphate with a harmful effect on the environment due to their toxicity, as well as a corrosive effect on waste lines. To overcome these problems, the eco-friendliness of alkaline protease, together with iron (II) sulphate $\left(\mathrm{FeSO}_{4}\right)$ as a reducing agent, was studied as a replacement for sodium dithionite. Dyed samples were characterised by attenuated total reflection, using Fourier transformation infrared spectroscopy, scanning electron microscope and X-ray diffraction (XRD). It was observed that alkaline protease, together with iron (II) sulphate, is also capable of producing a comparable reduction potential in dye baths, reduction bath stability, and the surface colour strength and colour fastness properties of dyed cotton compared to those obtained using sodium dithionite.
\end{abstract}

Keywords: indigo, protease, colour strength, sodium dithionite, ferrous sulphate

\section{Izvleček}

Indigo se na bombažu uporablja vedno z namenom, da dobimo privlačen modri odtenek, skupaj z želenimi učinki izpranosti. Indigo je v vodi netopen. Da razvije afiniteto do bombaža, ga je treba reducirati in solubilizirati z natrijevim ditionitom in NaOH. Pri disociiaciji natrijevega ditionita nastanejo nevarni stranski produkti, in sicer sulfatni, sulfitni in tiosulfatni ioni, ki zaradi strupenosti in korozivnega učinka škodljivo vplivajo na cevni sistem odpadne vode. Da bi odpravili te težave, je bila namesto natrijevega ditionita preučevana okolju prijazna alkalna proteaza skupaj z železovim (II) sulfatom (FeSO 4 ) kot reducentom. Obarvani vzorci so bili analizirani s pomočjo spektroskopije FTIR ATR, rastrske elektronske mikroskopije, in rentgenske difrakcije (XRD). Pokazalo se je, da v primerjavi z natrijevim ditionitom dosežemo z alkalno proteazo in železovim (II) sulfatom primerljiv redukcijski potencial v barvalnih kopelih, stabilne redukcijske kopeli, površinsko močno obarvanje in barvno obstojnosti na bombažu.

Ključne besede: indigo, proteaza, intenzivnost obarvanja, natrijev ditionit, železov sulfat

\section{Introduction}

Indigo is one of the oldest and the most frequently used dyes to produce the attractive blue shade, together with the desired wash-down effect on denim [1]. Indigo is water insoluble, and is used to develop an affinity for cotton in the presence of a reducing agent and alkali.

Corresponding author/Korespondenčni avtor:

J N Chakraborty

E-mail: chakrabortyjn@gmail.com
Solubilised indigo is generally applied using the ' 6 dip 6 nip' technique with dithionite $\left(\mathrm{Na}_{2} \mathrm{~S}_{2} \mathrm{O}_{4}\right)$ as a reducing agent and sodium hydroxide as an alkali [2]. Sodium dithionite is thermally, hydrolytically and oxidatively unstable, and easily oxidised by atmospheric oxygen, while stability is reduced with an increase in temperature, even in absence of oxygen. Some of the

Tekstilec, 2019, 62(3), 187-199

DOI: 10.14502/Tekstilec2019.62.187-199 
by-products formed due to the decomposition of sodium dithionite are sulphur compounds (e.g. $\mathrm{Na}_{2} \mathrm{~S}$, $\mathrm{NaHS}$, etc.), which pollute the atmosphere through the formation of hydrogen sulphide. At the same time, sulphur salts in the form of sulphates and sulphites $\left(\mathrm{Na}_{2} \mathrm{SO}_{3}, \mathrm{NaHSO}_{4}, \mathrm{Na}_{2} \mathrm{SO}_{4}\right.$ and $\left.\mathrm{Na}_{2} \mathrm{~S}_{2} \mathrm{O}_{3}\right)$ contaminate sewage, lower its $\mathrm{pH}$ and corrode concrete supply and drainage pipes [3]. Other problems associated with the use of sodium dithionite relate to costs and storage.

The problems associated with the use of $\mathrm{Na}_{2} \mathrm{~S}_{2} \mathrm{O}_{4}$ have led to the search for alternative, non-dithionitebased reduction systems. These include the application of iron (II) salts, together with gluconic acid and $\mathrm{NaOH}$ at $60^{\circ} \mathrm{C}$ [3-5], and iron (II) salts in combination with tartaric or citric acid, triethanolamine and $\mathrm{NaOH}$ at room temperature [6-7]. All these reduction systems showed results comparable to sodium dithionite with some exceptions.

In recent years, the use of eco-friendly materials, such as enzymes for sustainable textile processing has emerged $[9,10]$. Enzymes belonging to oxidoreductases and hydrolases categories play an important role in the reduction of dye in alkaline media. One of those enzymes, e.g. alkaline protease belonging to the hydrolases category with nomenclature 3.4. $x$, has been found to be useful in the reduction of sulphur dye $[11,12]$. It is used for various industrial purposes, such as detergents, waste management, food, leather, silver recovery and textiles, to improve the shrinkage resistance of wool, for bioblasting and for the removal of sericin [13-23]. Alkaline protease possesses many characteristic features, such as its stability at high temperature at an alkaline $\mathrm{pH}[18,24]$.

This work studied the application of alkaline protease, together with iron (II) sulphate as a reducing agent, for the dyeing of cotton with indigo. Pre-treated cotton was dyed with reduced and solubilised indigo using sodium dithionite and alkaline proteases separately using the ' 6 dip 6 nip' technique. The Box-Behnken response surface design was used to analyse the performance of alkaline protease, together with iron (II) sulphate, to achieve the optimised parameters and performance of both reduction systems in terms of $\mathrm{pH}$, the reduction potential $(\mathrm{mV})$ at various stages of dyeing, the surface colour strength $(\mathrm{K} / \mathrm{S})$ of dyed cotton, the stability of the reduction bath, and the fastness properties and tensile strength of dyed cotton. The characteristics and surface morphology of dyed cotton were evaluated using ATR-FTIR, XRD and SEM.

\section{Materials and methods \\ 2.1 Materials and chemicals}

Thoroughly pre-treated and mercerised cotton fabric $(35.4 \mathrm{ends} / \mathrm{cm}, 28.3$ picks $/ \mathrm{cm}$, linear density of warp yarn of 19.7 tex, linear density of weft yarn of 29.5 tex and mass per unit area of $155 \mathrm{~g} / \mathrm{m}^{2}$ ) was used in this study.

Alkaline protease (EC 3.4.21.63) and indigo (C.I. vat blue 1) were procured from Maps Enzymes, Ahmedabad and Dystar, Mumbai respectively, while iron (II) sulphate (99.5\%), sodium hydroxide (96\%) and sodium dithionite $(87-88 \%)$ were procured from SD Fine chemicals.

\section{Preparation of padding liquor}

a) Sodium dithionite and $\mathrm{NaOH}$ system

A stock vat and dilution liquor were used to prepare the required concentration of indigo padding liquor (Table 1). To prepare the stock vat, the required amount of sodium hydroxide $(\mathrm{NaOH})$ and indigo were added to $100 \mathrm{ml}$ water and heated to $50^{\circ} \mathrm{C}$. The required amount of sodium dithionite $\left(\mathrm{Na}_{2} \mathrm{~S}_{2} \mathrm{O}_{4}\right)$ was then added and the solution left to sit for 15-20 minutes to complete the reduction of the indigo.

To prepare the dilution liquor, the required amount of $\mathrm{NaOH}$ and $\mathrm{Na}_{2} \mathrm{~S}_{2} \mathrm{O}_{4}$ was added to 1 litre of water at room temperature and stirred well until a clear solution was obtained.

A padding liquor with $3 \mathrm{~g} / \mathrm{l}$ indigo was prepared from these two solutions. A total of $567 \mathrm{ml}$ of dilution liquor was added to $100 \mathrm{ml}$ of the reduced stock vat to make $667 \mathrm{ml}$ of padding liquor solution. The concentrations of dye, $\mathrm{NaOH}$ and $\mathrm{Na}_{2} \mathrm{~S}_{2} \mathrm{O}_{4}$ to prepare the stock vat and dilution liquor were as detailed below (as per guidelines of BASF) to prepare control.

Table 1: BASF guidelines for preparing the stock indigo solution

\begin{tabular}{|l|c|c|c|}
\hline Substance & $\begin{array}{c}\text { Stock } \\
\text { vat }[\mathrm{g} / \mathrm{l}]\end{array}$ & $\begin{array}{c}\text { Dilution } \\
\text { liquor }[\mathrm{g} / \mathrm{l}]\end{array}$ & $\begin{array}{c}\text { Padding } \\
\text { liquor }[\mathrm{g} / \mathrm{l}]\end{array}$ \\
\hline $\mathrm{Dye}$ & 20 & - & - \\
\hline $\mathrm{NaOH}$ & 20 & 1.35 & 4.416 \\
\hline $\mathrm{Na}_{2} \mathrm{~S}_{2} \mathrm{O}_{4}$ & 20 & 2.0 & 4.698 \\
\hline
\end{tabular}


b) Alkaline protease and iron (II) sulphate system In this case, the padding liquor was prepared in the same manner used for the dithionite system, with only difference being the use of protease, together with iron (II) sulphate, instead of dithionite.

\section{Dyeing of cotton with indigo}

Cotton was dyed with reduced indigo from both reduction systems using the ' 6 dip 6 nip' padding technique. This included the dipping of cotton in the dye liquor for 30 seconds, followed by padding at a pressure of $1 \mathrm{~kg} / \mathrm{cm}^{2}$ for $75-80 \%$ of pick up and airing for 1 minute to complete the ' 1 dip 1 nip' cycle. The cotton fabric was dyed in six such consecutive cycles with final airing for 3 minutes to convert the reduced dye on the fabric to its oxidised form. The dyed samples were then thoroughly washed in hot water.

\section{Statistical analysis of dyed cotton}

The Box-Behnken response surface design was used to analyse and optimise process parameters. This included identifying the best suitable combinations of parameters and the levels thereof to achieve a dye strength $(\mathrm{K} / \mathrm{S})$ equivalent to that obtained in the dithionite system. Five dyeing parameters were studied: the concentration of $\mathrm{FeSO}_{4}, \mathrm{NaOH}$, alkaline protease, indigo and temperature. These factors, with their coded values according to the $3^{5}$ BoxBehnken experimental design, are presented in Table 2. Using these five parameters (factors), each with three levels, a $3^{5}$ Box-Behnken design was run to obtain a set of data (run), consisting of a total of 46 runs with six replicates at the central point. The design run is presented in Table 3. The results were analysed using response surface plots and equations were formed for a response at a 95\% confidence level. Response surface figures were analysed to understand

Table 2: Inputs with coded values

\begin{tabular}{|c|c|c|c|c|}
\hline \multirow{2}{*}{$\begin{array}{l}\text { Coded } \\
\text { factor }\end{array}$} & \multirow{2}{*}{$\begin{array}{c}\text { Factors } \\
\text { (independent } \\
\text { variables) }\end{array}$} & \multicolumn{3}{|c|}{ Levels } \\
\hline & & low & $\begin{array}{l}\text { me- } \\
\text { dium }\end{array}$ & high \\
\hline $\mathrm{A}$ & Ferrous sulphate & -1 & 0 & +1 \\
\hline $\mathrm{B}$ & Sodium hydroxide & -1 & 0 & +1 \\
\hline $\mathrm{C}$ & Alkaline protease & -1 & 0 & +1 \\
\hline $\mathrm{D}$ & Indigo & -1 & 0 & +1 \\
\hline $\mathrm{E}$ & Temperature & -1 & 0 & +1 \\
\hline
\end{tabular}

Table 3: Scheme of experimental runs

\begin{tabular}{|c|c|c|c|c|c|}
\hline Run & $\mathrm{FeSO}_{4}$ & $\mathrm{NaOH}$ & Protease & Dye & $\begin{array}{c}\text { Tempe- } \\
\text { rature }\end{array}$ \\
\hline 1 & -1 & -1 & 0 & 0 & 0 \\
\hline 2 & 1 & -1 & 0 & 0 & 0 \\
\hline 3 & -1 & 1 & 0 & 0 & 0 \\
\hline 4 & 1 & 1 & 0 & 0 & 0 \\
\hline 5 & 0 & 0 & -1 & -1 & 0 \\
\hline 6 & 0 & 0 & 1 & -1 & 0 \\
\hline 7 & 0 & 0 & -1 & 1 & 0 \\
\hline 8 & 0 & 0 & 1 & 1 & 0 \\
\hline 9 & 0 & -1 & 0 & 0 & -1 \\
\hline 10 & 0 & 1 & 0 & 0 & -1 \\
\hline 11 & 0 & -1 & 0 & 0 & 1 \\
\hline 12 & 0 & 1 & 0 & 0 & 1 \\
\hline 13 & -1 & 0 & -1 & 0 & 0 \\
\hline 14 & 1 & 0 & -1 & 0 & 0 \\
\hline 15 & -1 & 0 & 1 & 0 & 0 \\
\hline 16 & 1 & 0 & 1 & 0 & 0 \\
\hline 17 & 0 & 0 & 0 & -1 & -1 \\
\hline 18 & 0 & 0 & 0 & 1 & -1 \\
\hline 19 & 0 & 0 & 0 & -1 & 1 \\
\hline 20 & 0 & 0 & 0 & 1 & 1 \\
\hline 21 & 0 & -1 & -1 & 0 & 0 \\
\hline 22 & 0 & 1 & -1 & 0 & 0 \\
\hline 23 & 0 & -1 & 1 & 0 & 0 \\
\hline 24 & 0 & 1 & 1 & 0 & 0 \\
\hline 25 & -1 & 0 & 0 & -1 & 0 \\
\hline 26 & 1 & 0 & 0 & -1 & 0 \\
\hline 27 & -1 & 0 & 0 & 1 & 0 \\
\hline 28 & 1 & 0 & 0 & 1 & 0 \\
\hline 29 & 0 & 0 & -1 & 0 & -1 \\
\hline 30 & 0 & 0 & 1 & 0 & -1 \\
\hline 31 & 0 & 0 & -1 & 0 & 1 \\
\hline 32 & 0 & 0 & 1 & 0 & 1 \\
\hline 33 & -1 & 0 & 0 & 0 & -1 \\
\hline 34 & 1 & 0 & 0 & 0 & -1 \\
\hline 35 & -1 & 0 & 0 & 0 & 1 \\
\hline 36 & 1 & 0 & 0 & 0 & 1 \\
\hline 37 & 0 & -1 & 0 & -1 & 0 \\
\hline 38 & 0 & 1 & 0 & -1 & 0 \\
\hline 39 & 0 & -1 & 0 & 1 & 0 \\
\hline 40 & 0 & 1 & 0 & 1 & 0 \\
\hline 41 & 0 & 0 & 0 & 0 & 0 \\
\hline 42 & 0 & 0 & 0 & 0 & 0 \\
\hline 43 & 0 & 0 & 0 & 0 & 0 \\
\hline 44 & 0 & 0 & 0 & 0 & 0 \\
\hline 45 & 0 & 0 & 0 & 0 & 0 \\
\hline 46 & 0 & 0 & 0 & 0 & 0 \\
\hline
\end{tabular}


the effect of an individual parameter (factor) on dye strength (K/S). A regression equation was formed accordingly. All design formations and statistical analysis were carried out using Design Expert 7 software. A quadratic polynomial was used to analyse the relationship of dye strength (K/S) (response) with five independent variables (factors) for Box-Behnken design runs. The accuracy of the model was verified using the coefficient of determination $\left(R^{2}\right)$ to the measure the goodness of fit to the model. When $\mathrm{R}^{2}$ approaches unity, the empirical model fits the actual data. P-values of less than 0.05 were considered to be statistically significant. The lack-of-fit test was analysed to check the adequacy of the model. Two techniques, i.e. the response surface figures technique and the regression equation technique, were used to predict the optimised combination of the factors that result in maximum colour strength $(\mathrm{K} / \mathrm{S})$.

\section{Evaluation of dye bath and dyed cotton}

The surface colour strength $(\mathrm{K} / \mathrm{S})$ of dyed cotton was evaluated using a computer colour match (Datacolor Check, Datacolor International, US), while colour fastness properties, such as light, wash and rubbing, were evaluated using AATCC test methods 16-2004 (light), 61-2007 (wash), 8-2007 (rubbing) respectively. Reduction dye baths were evaluated in terms of $\mathrm{pH}$ and reduction potential using a digital pH cum ORP meter (Century Instruments, Chandigarh, India) at various stages of dyeing i.e. before and after the reduction of the dye, as well as after the completion of the dye.

\section{Estimation of dye uptake}

To study the amount of indigo uptake on cotton fabric after each dip and nip, the known weight of dyed cotton fabric was dissolved in dimethyl sulfoxide (DMSO) to extract indigo from the dyed cotton fabric. The extract was analysed using a UV-Vis spectrophotometer (Perkin Elmer) to evaluate the mass of indigo $(\mathrm{g})$ per $100 \mathrm{~g}$ of cotton fabric after each padding-nipping-airing cycle.

\section{Stability of reduction dye baths}

Reduction baths in sodium dithionite and alkaline protease, together with iron (II) salt, were prepared in the absence of dye and stored for a specific period (0-24 hours) at room temperature, after which $\mathrm{pH}$ and reduction potential $(-\mathrm{mV})$ were noted. Dye was added and the cotton fabric was dyed after reduction and solubilisation. To study the stability of reduction baths in the presence of dye, dye baths were prepared and stored for a specific period, and $\mathrm{pH}$ and $\mathrm{mV}$ were noted, followed by dyeing of the cotton fabric in these baths.

\section{$\mathrm{X}$-ray diffraction}

Diffractograms were generated using a Malvern Pan analytical XRD. A small sample was clamped into a sample holder on a goniometer (radius $240 \mathrm{~mm}$ ) in a scanning range of $10-60$ with a step size of $0.008^{\circ}$ and an $\mathrm{X}$-ray radiation wavelength of $\lambda=0.15406 \mathrm{~nm}$ using $\mathrm{Cu} \mathrm{K}{ }_{\alpha}$. The X-ray generator was operated at $40 \mathrm{~mA}$ and $45 \mathrm{kV}$. ATR-FTIR spectra were obtained using an ALPHA FT-IR spectrophotometer (Bruker, USA).

\section{Tensile strength of cotton fabric}

A universal testing machine (Aimil, Delhi) was used to measure the tensile strength of cotton fabric using an ASTM D5035 test method after dyeing in both reduction systems.

\section{Results and discussion}

\subsection{Dyeing of cotton with sodium dithionite}

Cotton fabric was dyed with indigo using the ' 6 dip 6 nip' padding technique, followed by oxidation and washing. The K/S of the dyed cotton was determined to be 22.40 at $\lambda \max 590 \mathrm{~nm}$. The range of $\mathrm{pH}$ and $\mathrm{mV}$ were 12.2 to 12.8 and $(-640 \mathrm{mV}$ to $-780 \mathrm{mV})$ respectively at various stages of dyeing.

\subsection{Dyeing of cotton with alkaline protease}

Efforts to dye cotton fabric with indigo using alkaline protease instead of sodium dithionite could not generate the required reduction potential nor any reduction of dye leading to no dye strength $(\mathrm{K} / \mathrm{S})$ on cotton. The reduction potential of the bath was in the range of $-330 \mathrm{mV}$ to $-370 \mathrm{mV}$. In contrast, indigo requires a reduction potential of around $-650 \mathrm{mV}$ and more for reduction. It was determined that enzyme activity is enhanced by the addition of metals to the bath $[25,26]$. For this reason, indigo reduction baths were formulated with alkaline protease, together with iron (II) sulphate. Cotton fabric was dyed in this bath in the same manner that is used in the dithionite system. The reduction potential of the bath was raised to around $-700 \mathrm{mV}$ to $-720 \mathrm{mV}$ with the reduction of indigo. The cotton fabric was 
then dyed with a lower K/S. To improve the K/S, the levels of dyeing parameters were varied, and the reduction baths were prepared by dyeing cotton from each bath to attempt to achieve the same dye strength on cotton that was obtained in the dithionite system. The more suitable ranges were concentrations of $\mathrm{FeSO}_{4}(20-25 \mathrm{~g} / \mathrm{l}), \mathrm{NaOH}(7.5-12 / 5 \mathrm{~g} / \mathrm{l})$, alkaline protease $(1-2 \mathrm{~g} / \mathrm{l})$, indigo $(7-8 \mathrm{~g} / \mathrm{l})$ and temperature $\left(60-80{ }^{\circ} \mathrm{C}\right)$. The actual values of levels in the BoxBehnken design were formed accordingly (Table 4).

Table 4: Process parameters and the coded levels thereof

\begin{tabular}{|c|l|c|c|c|}
\hline \multirow{2}{*}{$\begin{array}{c}\text { Coded } \\
\text { factor }\end{array}$} & \multicolumn{1}{|c|}{$\begin{array}{c}\text { Factors } \\
\text { (independent } \\
\text { variables) }\end{array}$} & $\begin{array}{c}-1 \\
(\text { low })\end{array}$ & $\begin{array}{c}0 \\
(\text { me- } \\
\text { dium })\end{array}$ & $\begin{array}{c}1 \\
\text { (high) }\end{array}$ \\
\hline $\mathrm{A}$ & $\begin{array}{l}\text { Ferrous } \\
\text { sulphate [g/l] }\end{array}$ & 20 & 22.5 & 25 \\
\hline $\mathrm{B}$ & $\begin{array}{l}\text { Sodium } \\
\text { hydroxide }[\mathrm{g} / \mathrm{l}]\end{array}$ & 7.5 & 10 & 12.5 \\
\hline $\mathrm{C}$ & $\begin{array}{l}\text { Alkaline } \\
\text { protease }[\mathrm{g} / \mathrm{l}]\end{array}$ & 1.0 & 1.5 & 2.0 \\
\hline $\mathrm{D}$ & Indigo $[\mathrm{g} / \mathrm{l}]$ & 7.0 & 7.5 & 8.0 \\
\hline $\mathrm{E}$ & $\begin{array}{l}\text { Temperature } \\
{\left[{ }^{\circ} \mathrm{C}\right]}\end{array}$ & 60 & 70 & 80 \\
\hline
\end{tabular}

Putting these levels in the Box-Behnken design resulted in 46 separate runs. Indigo baths were prepared based on these sets of parameters and levels, while the cotton fabric was dyed and the K/S was evaluated. The results are presented in Table 5.

It was observed that the range of K/S was 12.26 to 23.9, while the highest $\mathrm{K} / \mathrm{S}$ was observed if the bath

Table 5: Responses of Box-Behnken analysis

\begin{tabular}{|r|l|l|l|l|l|l|}
\hline Run & $\begin{array}{c}\mathrm{FeSO}_{4} \\
{[\mathrm{~g} / \mathrm{l}]}\end{array}$ & $\begin{array}{c}\mathrm{NaOH} \\
{[\mathrm{g} / \mathrm{l}]}\end{array}$ & $\begin{array}{c}\text { Pro- } \\
\text { tease } \\
{[\mathrm{g} / \mathrm{l}]}\end{array}$ & $\begin{array}{c}\text { In- } \\
\text { digo } \\
{[\mathrm{g} / \mathrm{l}]}\end{array}$ & $\begin{array}{c}\text { Tempe- } \\
\text { rature } \\
{\left[{ }^{\circ} \mathrm{C}\right]}\end{array}$ & $\mathrm{K} / \mathrm{S}$ \\
\hline 1 & 20 & 7.5 & 1.5 & 7.5 & 70 & 20.85 \\
\hline 2 & 25 & 7.5 & 1.5 & 7.5 & 70 & 12.26 \\
\hline 3 & 20 & 12.5 & 1.5 & 7.5 & 70 & 16.52 \\
\hline 4 & 25 & 12.5 & 1.5 & 7.5 & 70 & 18.76 \\
\hline 5 & 22.5 & 10 & 1 & 7 & 70 & 20.10 \\
\hline 6 & 22.5 & 10 & 2 & 7 & 70 & 18.81 \\
\hline 7 & 22.5 & 10 & 1 & 8 & 70 & 20.80 \\
\hline
\end{tabular}

\begin{tabular}{|r|l|l|l|l|l|l|}
\hline Run & $\begin{array}{c}\mathrm{FeSO}_{4} \\
{[\mathrm{~g} / \mathrm{l}]}\end{array}$ & $\begin{array}{c}\mathrm{NaOH} \\
{[\mathrm{g} / \mathrm{l}]}\end{array}$ & $\begin{array}{c}\text { Pro- } \\
\text { tease } \\
{[\mathrm{g} / \mathrm{l}]}\end{array}$ & $\begin{array}{c}\text { In- } \\
\text { digo } \\
{[\mathrm{g} / \mathrm{l}]}\end{array}$ & $\begin{array}{c}\text { Tempe- } \\
\text { rature } \\
{\left[{ }^{\circ} \mathrm{C}\right]}\end{array}$ & $\mathrm{K} / \mathrm{S}$ \\
\hline 8 & 22.5 & 10 & 2 & 8 & 70 & 18.66 \\
\hline 9 & 22.5 & 7.5 & 1.5 & 7.5 & 60 & 14.42 \\
\hline 10 & 22.5 & 12.5 & 1.5 & 7.5 & 60 & 16.74 \\
\hline 11 & 22.5 & 7.5 & 1.5 & 7.5 & 80 & 16.48 \\
\hline 12 & 22.5 & 12.5 & 1.5 & 7.5 & 80 & 17.87 \\
\hline 13 & 20 & 10 & 1 & 7.5 & 70 & 21.66 \\
\hline 14 & 25 & 10 & 1 & 7.5 & 70 & 21.50 \\
\hline 15 & 20 & 10 & 2 & 7.5 & 70 & 20.44 \\
\hline 16 & 25 & 10 & 2 & 7.5 & 70 & 19.28 \\
\hline 17 & 22.5 & 10 & 1.5 & 7 & 60 & 18.92 \\
\hline 18 & 22.5 & 10 & 1.5 & 8 & 60 & 16.23 \\
\hline 19 & 22.5 & 10 & 1.5 & 7 & 80 & 19.83 \\
\hline 20 & 22.5 & 10 & 1.5 & 8 & 80 & 20.09 \\
\hline 21 & 22.5 & 7.5 & 1 & 7.5 & 70 & 15.02 \\
\hline 22 & 22.5 & 12.5 & 1 & 7.5 & 70 & 19.35 \\
\hline 23 & 22.5 & 7.5 & 2 & 7.5 & 70 & 12.83 \\
\hline 24 & 22.5 & 12.5 & 2 & 7.5 & 70 & 23.68 \\
\hline 25 & 20 & 10 & 1.5 & 7 & 70 & 20.72 \\
\hline 26 & 25 & 10 & 1.5 & 7 & 70 & 22.33 \\
\hline 27 & 20 & 10 & 1.5 & 8 & 70 & 19.58 \\
\hline 28 & 25 & 10 & 1.5 & 8 & 70 & 22.27 \\
\hline 29 & 22.5 & 10 & 1 & 7.5 & 60 & 20.21 \\
\hline 30 & 22.5 & 10 & 2 & 7.5 & 60 & 20.12 \\
\hline 31 & 22.5 & 10 & 1 & 7.5 & 80 & 20.14 \\
\hline 32 & 22.5 & 10 & 2 & 7.5 & 80 & 17.31 \\
\hline 33 & 20 & 10 & 1.5 & 7.5 & 60 & 23.90 \\
\hline 34 & 25 & 10 & 1.5 & 7.5 & 60 & 22.65 \\
\hline 35 & 20 & 10 & 1.5 & 7.5 & 80 & 19.46 \\
\hline 36 & 25 & 10 & 1.5 & 7.5 & 80 & 16.69 \\
\hline 37 & 22.5 & 7.5 & 1.5 & 7 & 70 & 12.46 \\
\hline 38 & 22.5 & 12.5 & 1.5 & 7 & 70 & 19.85 \\
\hline 39 & 22.5 & 7.5 & 1.5 & 8 & 70 & 13.03 \\
\hline 40 & 22.5 & 12.5 & 1.5 & 8 & 70 & 22.58 \\
\hline 41 & 22.5 & 10 & 1.5 & 7.5 & 70 & 21.62 \\
\hline 42 & 22.5 & 10 & 1.5 & 7.5 & 70 & 21.45 \\
\hline 43 & 22.5 & 10 & 1.5 & 7.5 & 70 & 21.76 \\
\hline 44 & 22.5 & 10 & 1.5 & 7.5 & 70 & 21.15 \\
\hline 45 & 22.5 & 10 & 1.5 & 7.5 & 70 & 21.82 \\
\hline 46 & 22.5 & 10 & 1.5 & 7.5 & 70 & 21.70 \\
\hline
\end{tabular}


was prepared according to run 33 , i.e. $\mathrm{FeSO}_{4}(20 \mathrm{~g} / \mathrm{l})$, $\mathrm{NaOH}(10 \mathrm{~g} / \mathrm{l})$, alkaline protease $(1.5 \mathrm{~g} / \mathrm{l})$, indigo $(7.5 \mathrm{~g} / \mathrm{l})$ and temperature $\left(60^{\circ} \mathrm{C}\right)$. It should be noted that a $3 \mathrm{~g} / \mathrm{l}$ indigo bath resulted in a K/S of 22.40 in dithionite system.

\subsection{Influence of dyeing parameters on K/S}

The influence of process parameters on concentrations of $\mathrm{FeSO}_{4}, \mathrm{NaOH}$, protease and indigo, and temperature on $\mathrm{K} / \mathrm{S}$ was evaluated using the BoxBehnken design and response surface methodology. All of the main effects, two interaction factors and the cubic effect with R-square 0.97 obtained using ANOVA are presented in Table 6. The model was significant at a $95 \%$ confidence interval, as the value of 'Prob>F' was less than 0.05. In this case, the concentrations of $\mathrm{FeSO}_{4}, \mathrm{NaOH}$, protease and temperature were the significant model factors. The model equation is shown in coded form in equation 1.

$$
\begin{aligned}
\mathrm{K} / \mathrm{S}= & +21.58-1.30 \times \mathrm{A}+0.73 \times \mathrm{B}-0.82 \times \\
& \times \mathrm{C}-0.26 \times \mathrm{D}+1.00 \times \mathrm{E}+2.71 \times \mathrm{A} \times \mathrm{B}- \\
& -0.25 \times \mathrm{A} \times \mathrm{C}+0.27 \times \mathrm{A} \times \mathrm{D}-0.36 \times \mathrm{A} \times \\
& \times \mathrm{E}+1.63 \times \mathrm{B} \times \mathrm{C}+0.54 \times \mathrm{B} \times \mathrm{D}-0.69 \times
\end{aligned}
$$

Table 6: ANOVA table for K/S

\begin{tabular}{|l|c|r|c|c|c|c|}
\hline \multicolumn{1}{|c|}{ Source } & $\begin{array}{c}\text { Sum of } \\
\text { squares }\end{array}$ & df & Mean square & F value & $\begin{array}{c}\text { p-value } \\
\text { Prob }>\text { F }\end{array}$ & \\
\hline Model & 389.3755447 & 26 & 14.97598249 & 27.10551714 & $<0.0001$ & significant \\
\hline A-FeSO4 & 13.57205 & 1 & 13.57205 & 24.56449413 & $<0.0001$ & \\
\hline B-NaOH & 4.3218 & 1 & 4.3218 & 7.822166195 & 0.0115 & \\
\hline C-alkaline protease & 7.987008333 & 1 & 7.987008333 & 14.45594581 & 0.0012 & \\
\hline D-Dye & 0.785408333 & 1 & 0.785408333 & 1.421536053 & 0.2478 & \\
\hline E-temperature & 7.9401125 & 1 & 7.9401125 & 14.37106751 & 0.0012 & \\
\hline AB & 29.322225 & 1 & 29.322225 & 53.07124744 & $<0.0001$ & \\
\hline AC & 0.25 & 1 & 0.25 & 0.45248312 & 0.5093 & \\
\hline AD & 0.2916 & 1 & 0.2916 & 0.527776311 & 0.4764 & \\
\hline AE & 0.525625 & 1 & 0.525625 & 0.95134576 & 0.3416 & \\
\hline BC & 10.6276 & 1 & 10.6276 & 19.23523843 & 0.0003 & \\
\hline BD & 1.1664 & 1 & 1.1664 & 2.111105246 & 0.1626 & \\
\hline CE & 1.8769 & 1 & 1.8769 & 3.397062273 & 0.081 & \\
\hline DE & 2.1904 & 1 & 2.1904 & 3.964476106 & 0.061 & \\
\hline $\mathrm{A}^{2}$ & 0.040751515 & 1 & 0.040751515 & 0.073757491 & 0.7889 & \\
\hline$B^{2}$ & 125.0288727 & 1 & 125.0288727 & 226.2938178 & $<0.0001$ & \\
\hline $\mathrm{C}^{2}$ & 4.08509697 & 1 & 4.08509697 & 7.393749693 & 0.0136 & \\
\hline $\mathrm{D}^{2}$ & 8.510454545 & 1 & 8.510454545 & 15.40334811 & 0.0009 & \\
\hline $\mathrm{E}^{2}$ & 17.47396364 & 1 & 17.47396364 & 31.62669435 & $<0.0001$ & \\
\hline $\mathrm{A}^{2} \mathrm{E}$ & 34.72820417 & 1 & 34.72820417 & 62.85570472 & $<0.0001$ & \\
\hline $\mathrm{AC}^{2}$ & 2.522016667 & 1 & 2.522016667 & 4.564679882 & 0.0459 & \\
\hline $\mathrm{AD}^{2}$ & 15.07335 & 1 & 15.07335 & 27.28174576 & $<0.0001$ & \\
\hline $\mathrm{B}^{2} \mathrm{C}$ & 5.474252083 & 1 & 5.474252083 & 9.908026654 & 0.0053 & \\
\hline $\mathrm{B}^{2} \mathrm{D}$ & 3.504602083 & 1 & 3.504602083 & 6.343093143 & 0.0209 & \\
\hline $\mathrm{BC}^{2}$ & 24.9696 & 1 & 24.9696 & 45.19329007 & $<0.0001$ & \\
\hline $\mathrm{BD}^{2}$ & 32.66666667 & 1 & 32.66666667 & 59.12446104 & $<0.0001$ & \\
\hline $\mathrm{C}^{2} \mathrm{E}$ & 7.854704167 & 1 & 7.854704167 & 14.2164842 & 0.0013 & \\
\hline Residual & 10.49762917 & 19 & 0.552506798 & & & \\
\hline Lack of fit & 0.18989583 & 14 & 0.727849702 & 11.82598087 & 0.0065 & significant \\
\hline Pure error & 399.8731739 & 45 & & & & \\
\hline Cor total & 389.3755447 & 26 & 14.97598249 & 27.10551714 & $<0.0001$ & significant \\
\hline Model & & & & & & \\
\hline & & & & \\
\hline
\end{tabular}




$$
\begin{aligned}
& \times \mathrm{C} \times \mathrm{E}+0.74 \times \mathrm{D} \times \mathrm{E}+0.068 \times \mathrm{A}^{2}-3.78 \times \\
& \times \mathrm{B}^{2}-0.68 \times \mathrm{C}^{2}-0.99 \times \mathrm{D}^{2}-1.42 \times \mathrm{E}^{2}- \\
& -3.61 \times \mathrm{A}^{2} \times \mathrm{E}+0.97 \times \mathrm{A} \times \mathrm{C}^{2}+2.38 \times \mathrm{A} \times \\
& \times \mathrm{D}^{2}+1.35 \times \mathrm{B}^{2} \times \mathrm{C}+1.08 \times \mathrm{B}^{2} \times \mathrm{D}+3.06 \times \\
& \times \mathrm{B} \times \mathrm{C}^{2}+3.50 \times \mathrm{B} \times \mathrm{D}^{2}-1.72 \times \mathrm{C}^{2} \times \mathrm{E}(1)
\end{aligned}
$$

where, different values of $\mathrm{A}, \mathrm{B}, \mathrm{C}, \mathrm{D}$ and $\mathrm{E}$ are presented in Table 6. This equation can predict the theoretical $\mathrm{K} / \mathrm{S}$ of dyed samples for given dyeing parameters.

\subsubsection{Influence of $\mathrm{FeSO}_{4}$ and $\mathrm{NaOH}$ concentrations}

The combined effect of $\mathrm{FeSO}_{4}$ and $\mathrm{NaOH}$ concentrations on $\mathrm{K} / \mathrm{S}$ at a constant alkaline protease concentration, indigo concentration (moderate level) and temperature (lower level) is shown in Figure 1(a). A moderate level of $\mathrm{NaOH}(10 \mathrm{~g} / \mathrm{l})$ and $\mathrm{FeSO}_{4}$ $(20 \mathrm{~g} / \mathrm{l})$ resulted a maximum K/S of 23.9. Increasing the concentration of $\mathrm{FeSO}_{4}$ resulted in a decrease in the dye strength $(\mathrm{K} / \mathrm{S})$ of cotton. An increased concentration of $\mathrm{FeSO}_{4}$ may have decreased the concentration of $\mathrm{NaOH}$ in the dye bath due to the formation of insoluble $\mathrm{Fe}(\mathrm{OH})_{2}$, which may affect the solubility of reduced indigo.

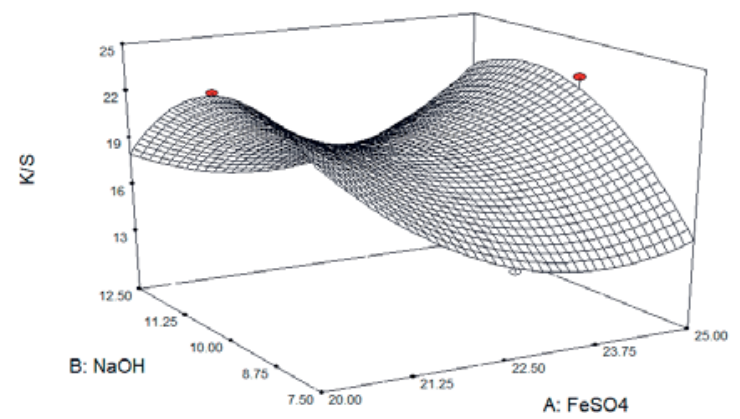

Figure 1a: Influence of dyeing parameters on K/S value of $\mathrm{FeSO}_{4}$ and $\mathrm{NaOH}$ concentrations,

\subsubsection{Influence of $\mathrm{FeSO}_{4}$ and protease concentrations}

The combined effect of $\mathrm{FeSO}_{4}$ and alkaline protease concentrations on $\mathrm{K} / \mathrm{S}$ at constant indigo and $\mathrm{NaOH}$ concentrations (medium level) and temperature (lower level) is shown in Figure 1(b). A lower level of $\mathrm{FeSO}_{4}$ concentration $(20 \mathrm{~g} / \mathrm{l})$ and a moderate level of protease concentration $(1.5 \mathrm{~g} / \mathrm{l})$ resulted in a maximum K/S of 23.9 with a reduction potential in the range of $(-660$ to -720$) \mathrm{mV}$ before and after the reduction of the dye, and at the end of dyeing. Increasing the concentration of $\mathrm{FeSO}_{4}$ decreased the $\mathrm{K} / \mathrm{S}$ of dyed cotton to 22.6 , which may be due to the partial reduction of indigo. $\mathrm{FeSO}_{4}$ reacts with $\mathrm{NaOH}$

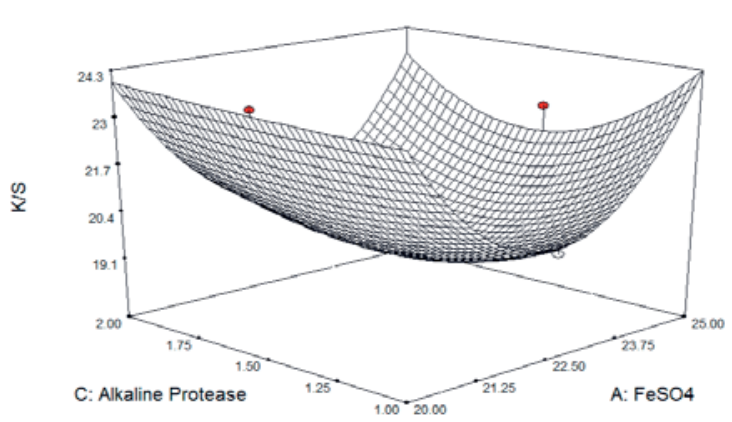

Figure 1b: Influence of dyeing parameters on K/S value of $\mathrm{FeSO}_{4}$ and protease concentrations

to form $\mathrm{Fe}(\mathrm{OH})_{2}$, resulting in a decrease in the effective concentration of sodium hydroxide (moderate level) in dye baths.

\subsubsection{Influence of $\mathrm{FeSO}_{4}$ and temperature}

The combined effect of $\mathrm{FeSO}_{4}$ concentration and temperature on $\mathrm{K} / \mathrm{S}$ at constant alkaline protease, indigo and $\mathrm{NaOH}$ concentrations (moderate level) is shown in Figure 1(c). A lower level of $\mathrm{FeSO}_{4}$ concentration and temperature resulted in a maximum $\mathrm{K} / \mathrm{S}$ of 23.9. Increasing the $\mathrm{FeSO}_{4}$ concentration and temperature resulted in a decrease in the K/S of dyed cotton to 16.69. In this case, protease was probably not completely activated to reduce indigo.

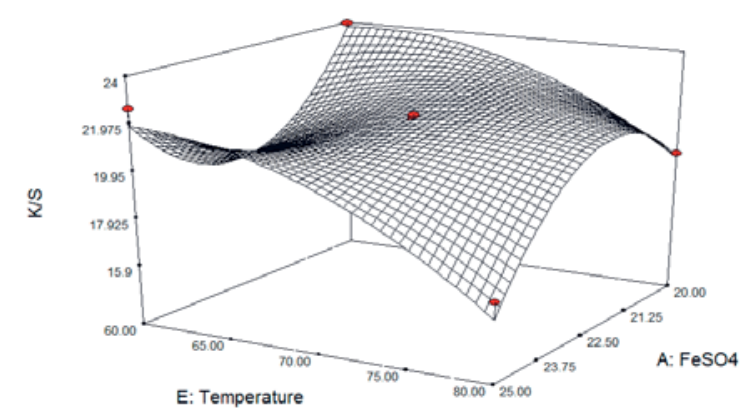

Figure 1c: Influence of dyeing parameters on $\mathrm{K} / \mathrm{S} \mathrm{val}$ ue of $\mathrm{FeSO}_{4}$ and temperature

\subsubsection{Influence of protease concentration and temperature}

The combined effect of protease concentration and temperature on $\mathrm{K} / \mathrm{S}$ at constant indigo and $\mathrm{NaOH}$ concentrations (moderate level) and $\mathrm{FeSO}_{4}$ (lower level) is shown in Figure 1(d). A moderate level of protease concentration and a lower temperature level resulted in a maximum $\mathrm{K} / \mathrm{S}$ of 23.9. Increasing the temperature resulted in a decrease in K/S to 


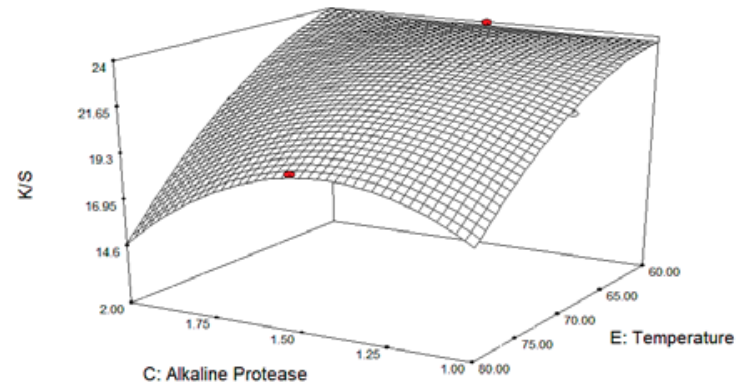

Figure 1d: Influence of dyeing parameters on K/S value of protease concentration and temperature

19.46 at a moderate level of protease concentration. The hydrolytic property of alkaline protease was activated at a specific temperature, resulting in a reduction in indigo.

\subsection{Indigo uptake and surface colour strength}

The dye uptake ( $\mathrm{g}$ of dye/100 g cotton) after each $\mathrm{dip} /$ nip was evaluated and is shown in Figure 2(a). The respective K/S after each dip/nip against that of indigo uptake is shown in Figure 2(b). K/S and dye uptake both increased proportionately. Although final K/S was nearly identical in both reduction systems, total dye uptake was found to be higher in the protease system despite a lower K/S in the protease system after the first dip/nip compared to that in the dithionite system. The same $\mathrm{K} / \mathrm{S}$ in both the cases with a variation in dye uptake facilitated more diffusion of dye into cotton in the protease system.

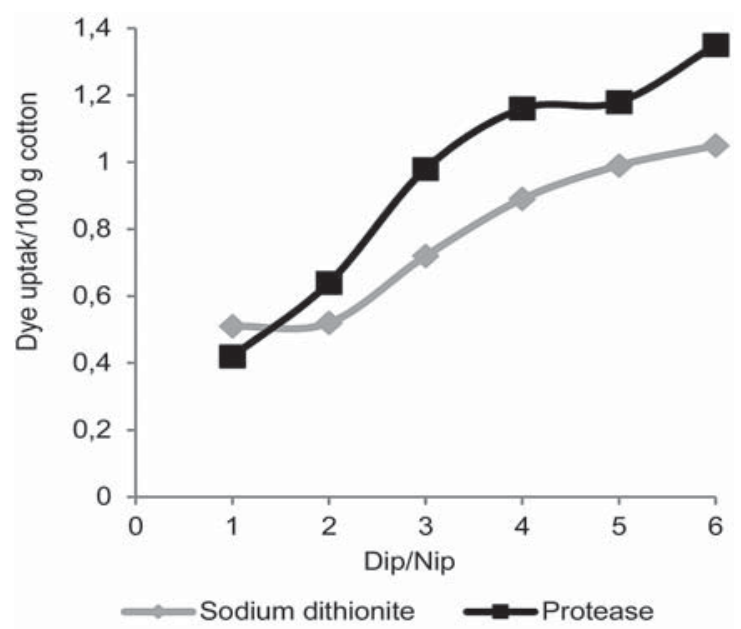

Figure 2a: Indigo uptake and surface colour strength dye uptake of cotton after each dip/nip

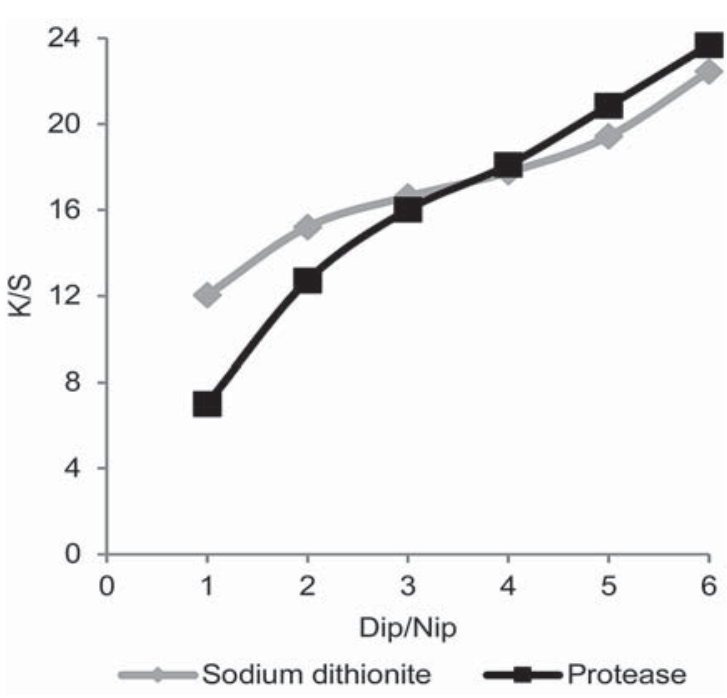

Figure 2b: Indigo uptake and surface colour strength dye strength $(K / S)$ of cotton after each dip/nip

\subsection{Stability of reduction baths}

\subsubsection{In the absence of dye}

The stability of reduction baths with $\mathrm{Na}_{2} \mathrm{~S}_{2} \mathrm{O}_{4}$ and alkaline protease was studied in the absence of dye for up to 24 hours. Reduction baths were prepared and covered. After storing them for a specific period of time, the $\mathrm{pH}$ and reduction potential of the baths were measured. Indigo was then added to the baths. Dyeing was carried out, with the results presented in Table 7. Both of the reduction systems retained their reduction capability for up to 24 hours. There was a progressive drop in $\mathrm{mV}$ and $\mathrm{pH}$ in both reduction baths with the passage of time. K/S gradually decreased with an increase in storage time in both reduction systems and is shown in Figure 3(a). Although reduction baths in both systems showed good stability over a 24 -hour period, maximum surface colour strength was observed for dyeing at 0 hours.

\subsubsection{In the presence of dye}

Reduction baths with $\mathrm{Na}_{2} \mathrm{~S}_{2} \mathrm{O}_{4}$ and alkaline protease were prepared, followed by the addition of indigo. The baths were covered and stored for up to 24 hours. The results were noted in terms of $\mathrm{pH}$ and reduction potential, and are presented in Table 8 .

Both of the reduction systems retained their reduction capability for 24 hours. There was a steady drop in the $\mathrm{mV}$ and $\mathrm{pH}$ of both reduction baths with the passage of time, while the proportionate drop in K/S 
Table 7: Stability of reduction baths in the absence of dye

\begin{tabular}{|c|c|c|c|c|c|c|c|c|c|c|c|c|}
\hline \multirow{3}{*}{$\begin{array}{l}\text { Time } \\
\text { (h) }\end{array}$} & \multicolumn{4}{|c|}{ Before reduction of dye } & \multicolumn{4}{|c|}{ After reduction of dye } & \multicolumn{4}{|c|}{ After completion of dyeing } \\
\hline & \multicolumn{2}{|c|}{$\mathrm{pH}$} & \multicolumn{2}{|c|}{$\begin{array}{c}\text { Reduction } \\
\text { potential } \\
{[\mathrm{mV}]}\end{array}$} & \multicolumn{2}{|c|}{$\mathrm{pH}$} & \multicolumn{2}{|c|}{$\begin{array}{c}\text { Reduction } \\
\text { potential } \\
{[\mathrm{mV}]}\end{array}$} & \multicolumn{2}{|c|}{$\mathrm{pH}$} & \multicolumn{2}{|c|}{$\begin{array}{c}\text { Reduction } \\
\text { potential } \\
{[\mathrm{mV}]}\end{array}$} \\
\hline & Hydro & Pro & Hydro & Pro & Hydro & Pro & Hydro & Pro & Hydro & Pro & Hydro & Pro \\
\hline 0 & 12.74 & 12.64 & -772 & -715 & 12.60 & 12.53 & -760 & -709 & 12.30 & 12.34 & -748 & -695 \\
\hline 1 & 12.74 & 12.58 & -765 & -712 & 12.38 & 12.46 & -755 & -7 & 12.18 & 12.26 & -750 & -692 \\
\hline 2 & 12.73 & 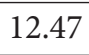 & -770 & -7 & 12.29 & 12 & -76 & - & 12.09 & 12.35 & -720 & -690 \\
\hline 4 & 12.72 & 12.55 & -782 & -705 & 12.5 & 12.45 & -740 & -695 & 12.10 & 12.29 & -730 & -685 \\
\hline 8 & 12.70 & 12.51 & -776 & -706 & 12.30 & 12.3 & -720 & -698 & 12.19 & 12.32 & -697 & -682 \\
\hline 12 & 12.72 & 12.55 & -780 & -718 & 12.34 & 12.48 & -729 & -707 & 12.12 & 12.42 & -695 & -670 \\
\hline 24 & 12.66 & 12.50 & -776 & -701 & 12.2 & 12.35 & -714 & -690 & 12.05 & 12.24 & -685 & -680 \\
\hline
\end{tabular}

Table 8: Stability of reduction baths in the presence of dye

\begin{tabular}{|c|c|c|c|c|c|c|c|c|c|c|c|c|}
\hline \multirow{3}{*}{$\begin{array}{l}\text { Time } \\
\text { (h) }\end{array}$} & \multicolumn{4}{|c|}{ Before reduction of dye } & \multicolumn{4}{|c|}{ After reduction of dye } & \multicolumn{4}{|c|}{ After completion of dyeing } \\
\hline & \multicolumn{2}{|c|}{$\mathrm{pH}$} & \multicolumn{2}{|c|}{$\begin{array}{c}\text { Reduction } \\
\text { potential } \\
{[\mathrm{mV}]}\end{array}$} & \multicolumn{2}{|c|}{$\mathrm{pH}$} & \multicolumn{2}{|c|}{$\begin{array}{c}\text { Reduction } \\
\text { potential } \\
{[\mathrm{mV}]}\end{array}$} & \multicolumn{2}{|c|}{$\mathrm{pH}$} & \multicolumn{2}{|c|}{$\begin{array}{c}\text { Reduction } \\
\text { potential } \\
{[\mathrm{mV}]}\end{array}$} \\
\hline & Hydro & Pro & Hydro & Pro & ydro & ro & Hydro & Pro & Hydro & Pro & Hydro & Pro \\
\hline 0 & 12.51 & 12.66 & & & 18 & 12.45 & 01 & & 12.35 & 2.32 & & -667 \\
\hline 1 & 12.49 & 12.49 & -716 & -715 & 12.45 & 12.35 & -705 & -712 & 12.35 & 12.25 & 10 & -655 \\
\hline 2 & & & & & & & . & & 12.26 & & & -676 \\
\hline 4 & 12.48 & 12.48 & -705 & -705 & 12.44 & 12.33 & -695 & -698 & 12.13 & 2.29 & 0 & -655 \\
\hline 8 & 12.48 & 12.55 & -718 & -709 & 12.44 & 12.35 & -707 & -701 & 12.04 & 12.25 & -590 & -686 \\
\hline 12 & 12.49 & 12.61 & -701 & -712 & 12.42 & 12.5 & -689 & -710 & 11.8 & 12.35 & -550 & -664 \\
\hline 24 & 12.48 & 12.52 & -704 & -706 & 12.41 & 12.47 & -685 & -690 & 11.5 & 12.40 & -489 & -676 \\
\hline
\end{tabular}

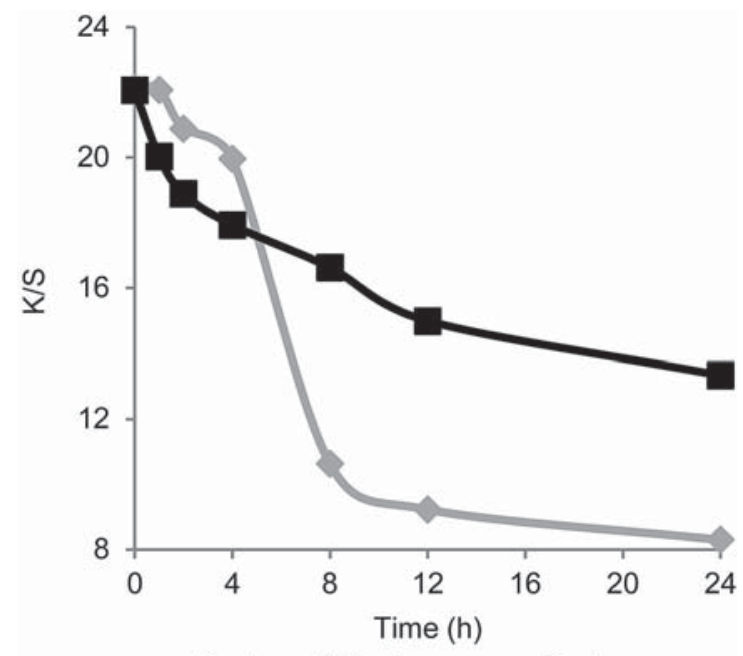

$\longrightarrow$ Sodium dithionite $\longrightarrow$ Protease

Figure 3a: Surface colour strength of cotton after storage in the absence of dye

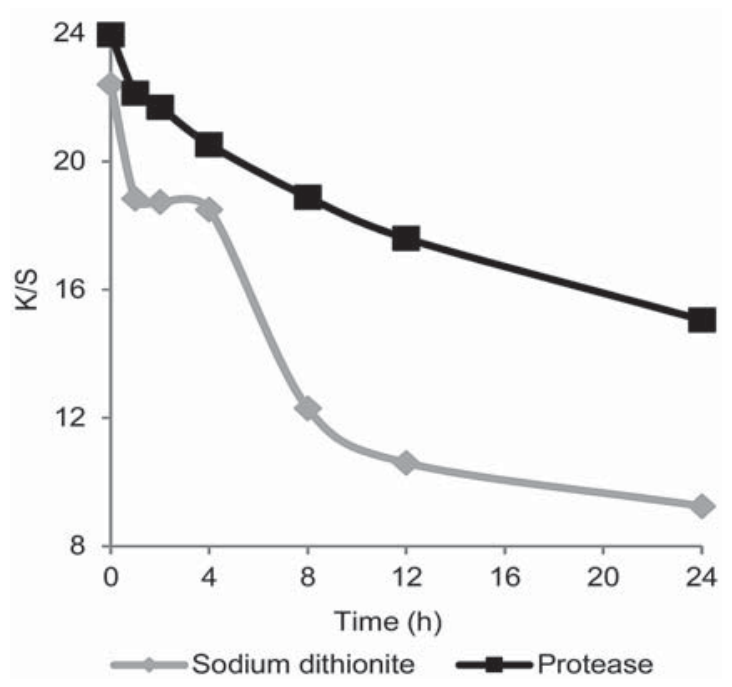

Figure 3b: Surface colour strength of cotton after storage in the presence of dye 
is also shown in figure 3(b). Reduced dye baths showed a maximum dye strength for dyeing at 0 hours, although good stability was observed for up to 24 hours.

\subsection{Characterisation}

\subsubsection{SEM analysis of dyed cotton fabric}

The surface morphology of dyed cotton was characterised using an SEM (Zeiss EVO 50) at a voltage of $10 \mathrm{kV}$ and a 5,000-x magnification. The surface of the cotton fibre was considered damaged due to dyeing. The SEM images of undyed cotton as well as cotton dyed using sodium dithionite and protease
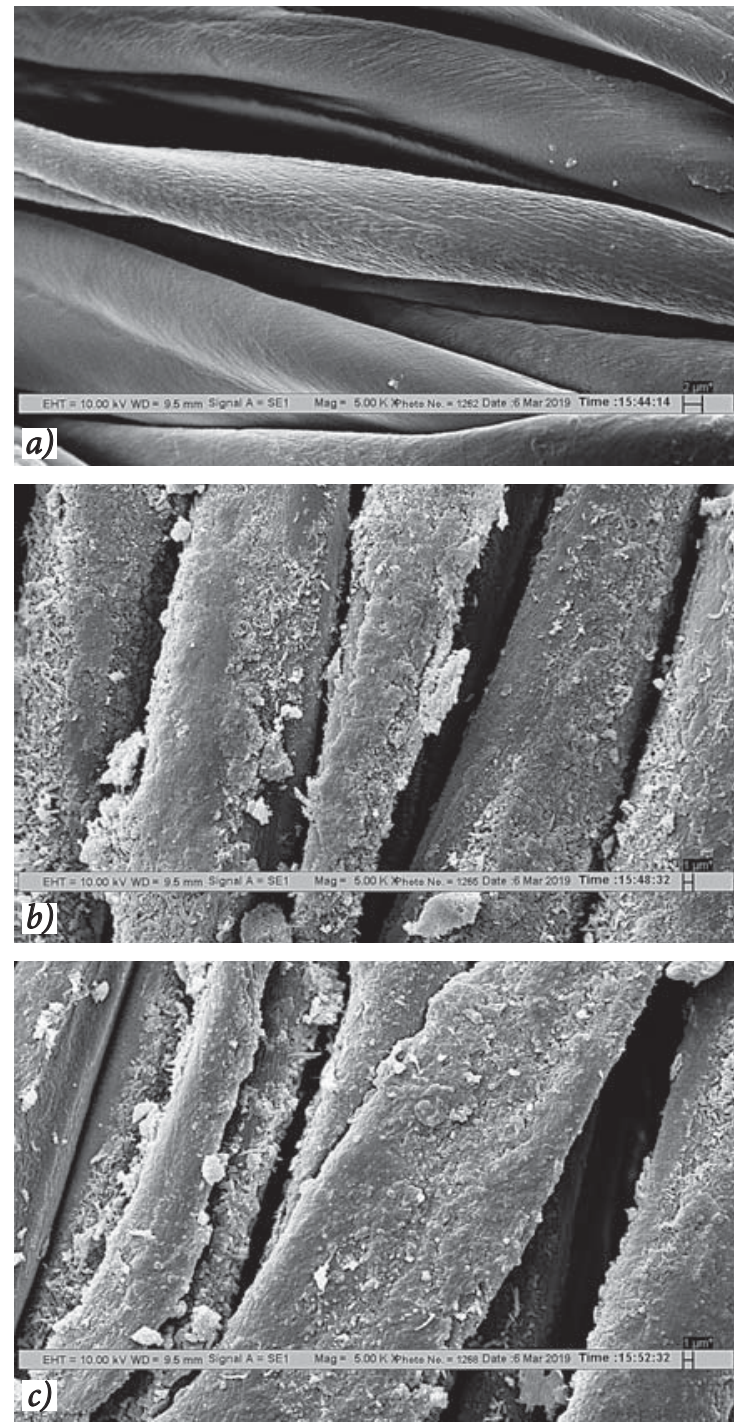

Figure 4: SEM images of: a) undyed cotton, b) dyed cotton using sodium dithionite and c) dyed cotton using alkaline protease systems are shown on Figure 4. The images show marginal damage on the surface of cotton dyed in the sodium dithionite system, which was not prominent in the protease system.

\subsubsection{ATR-FTIR of dyed cotton}

The spectra of dyed cotton with sodium dithionite and alkaline protease are compared with undyed cotton (control) and are shown in Figures 5(a) and 5(b) respectively. The absorption bands were mainly observed in the ranges of 3,869 to $2,850 \mathrm{~cm}^{-1}$ and 1,623 to $522 \mathrm{~cm}^{-1}$.

Strong band spectra were found in a range of 3,869$2,900 \mathrm{~cm}^{-1}$, as the result of the stretching vibration of $\mathrm{O}-\mathrm{H}$ and $\mathrm{C}-\mathrm{H}$ bonds, while the band peak at around $3,266-3,258 \mathrm{~cm}^{-1}$ is due to the stretching vibration of $\mathrm{R}-\mathrm{OH}$ in cellulose. This peak also includes inter- and intra-molecular hydrogen bonds [27-29]. The band peak of around $2,913 \mathrm{~cm}^{-1}$ to $2,849 \mathrm{~cm}^{-1}$ is due to the symmetrical and asymmetrical stretching of $-\mathrm{CH}_{2}$ groups in cellulose [30,31]. A typical band in the range of $1,623 \mathrm{~cm}^{-1}$ to $522 \mathrm{~cm}^{-1}$ was observed. The absorption band at $1,623 \mathrm{~cm}^{-1}$ to $1,619 \mathrm{~cm}^{-1}$ is characterised for the stretching of $\mathrm{C}=\mathrm{C}$ [18]. The
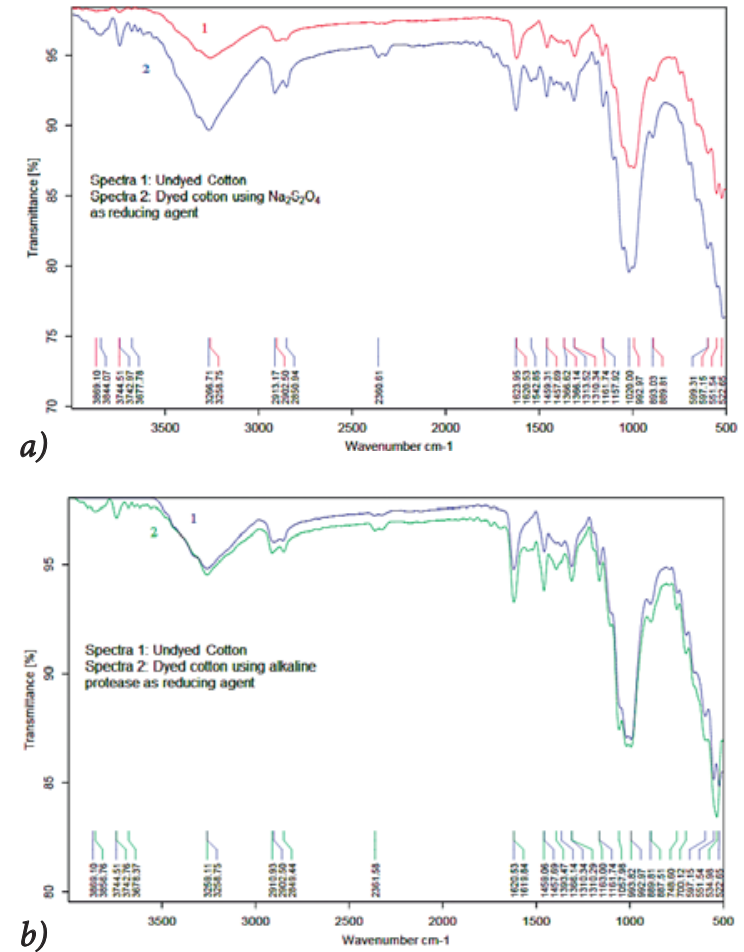

Figure 5: FTIR spectra of: a) undyed versus dyeing in dithionite system, and b) undyed versus dyeing in alkaline protease system 
band peaks at $1,459 \mathrm{~cm}^{-1}, 1,393 \mathrm{~cm}^{-1}, 1,366 \mathrm{~cm}^{-1}$, $1,310 \mathrm{~cm}^{-1}, 1,161 \mathrm{~cm}^{-1}$ and $1,057 \mathrm{~cm}^{-1}$ are characterised for the deformation or stretching vibrations of $\mathrm{C}=\mathrm{O}, \mathrm{C}-\mathrm{H}, \mathrm{C}-\mathrm{O}-\mathrm{C}, \mathrm{C}-\mathrm{O}, \mathrm{C}-\mathrm{N}, \mathrm{C}=\mathrm{C}$ and $\mathrm{N}-\mathrm{H}$ groups in cellulose, as well as indigo [32-34]. In Figure 5(b), differences were observed in the spectrum of dyed cotton using alkaline protease. There are changes in the absorption band in the range of $748 \mathrm{~cm}^{-1}$ to $700 \mathrm{~cm}^{-1}$, which is assigned to the inplane bending of the methyl group in cellulose [31]. The band spectra of both the sodium dithionite and alkaline protease systems were found to be nearly the same. It can thus be concluded that no chemical changes occurred in the new proposed reduction system.

\subsubsection{XRD of dyed cotton}

The X-ray diffractograms of undyed and dyed cotton are shown in Figure 6. The purpose of x-ray diffraction was to identify the loss in crystallinity of cotton due to a loss in tensile strength after dyeing. The degree of crystallinity is one of the most important parameters for a crystalline structure and was evaluated using Herman's method [28-35]. In this method, the crystallinity index was calculated by

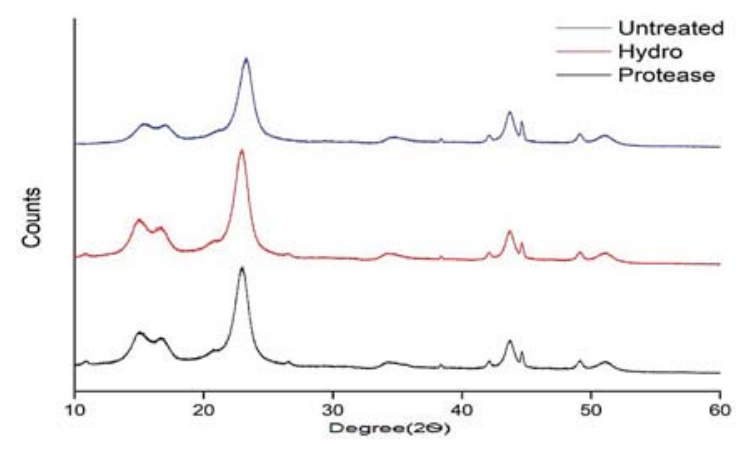

Figure 6: XRD diffractograms of undyed and dyed cotton in dithionite and alkaline protease systems the ratio of crystalline area to the total area of the $\mathrm{X}$-ray diffraction curve, as given equation 2 .

Crystallinity index $=\frac{A_{\text {Crystalline }}}{A_{\text {Total }}}(\%)$

where, $A_{\text {Crystaline }}$ is the crystalline area and $A_{\text {Total }}$ is area of X-ray diffraction curve.

The oxidation reaction of indigo may lead to a decrease in the degree of polymerisation of cellulose and may cause a loss in the tensile strength of cotton. This study revealed that crystallinity remained unchanged in the warp of dyed cotton in both reduction systems, although there was a marginal (7\%) drop in crystallinity in dyed cotton with dithionite, while the protease system did not result in a drop in the crystallinity of cotton (Table 9). Interestingly, the drop in tensile strength in the weft direction was similar in both systems, but marginal. The drop in the crystallinity index was also found to be around $7 \%$ in the dithionite system and $4 \%$ in the protease systems. This indicates that no significant damage occurred in the newly proposed protease-based reduction system.

\subsection{Fastness performance}

The light, rubbing and wash fastness of indigo-dyed cotton in the $\mathrm{Na}_{2} \mathrm{~S}_{2} \mathrm{O}_{4}$ and alkaline protease systems were evaluated and compared. The results are presented in Table 10. Light fastness remained very good to excellent in both the $\mathrm{Na}_{2} \mathrm{~S}_{2} \mathrm{O}_{4}$ and alkaline protease reduction systems. Wash fastness was also very good to excellent (4-5) in the alkaline protease system. Rubbing fastness was excellent, and very good to excellent in dry and wet conditions respectively. It can be concluded from the data that the new proposed alkaline protease-based reduction system proved to be a good and comparable match with the commercial sodium dithionite reduction system.

Table 9: Tensile strength and crystallinity index \% of undyed and dyed cotton

\begin{tabular}{|c|c|c|c|c|c|}
\hline \multirow[b]{2}{*}{ Sample } & \multicolumn{2}{|c|}{ Warp way } & \multicolumn{2}{|c|}{ Weft way } & \multirow[b]{2}{*}{$\begin{array}{c}\text { Crystallinity } \\
\text { index [\%] }\end{array}$} \\
\hline & $\begin{array}{l}\text { Breaking } \\
\text { strength } \\
{[\mathrm{N}]}\end{array}$ & $\begin{array}{c}\text { Loss in } \\
\text { strength } \\
{[\%]}\end{array}$ & $\begin{array}{c}\text { Breaking } \\
\text { strength } \\
{[\mathrm{N}]}\end{array}$ & $\begin{array}{c}\text { Loss in } \\
\text { strength } \\
{[\%]}\end{array}$ & \\
\hline Undyed cotton & 527 & - & 448 & - & 70.06 \\
\hline Dyed with sodium dithionite & 498.8 & 5.35 & 414.2 & 7.54 & 63.56 \\
\hline Dyed with alkaline protease & 501 & 4.93 & 433.8 & 3.17 & 66.62 \\
\hline
\end{tabular}


Table 10: Fastness performance of dyed cotton

\begin{tabular}{|l|c|c|c|c|c|}
\hline \multirow{2}{*}{$\begin{array}{c}\text { Dyeing } \\
\text { method }\end{array}$} & \multicolumn{2}{|c|}{ Wash fastness } & \multicolumn{2}{c|}{$\begin{array}{c}\text { Rubbing } \\
\text { fastness }\end{array}$} & $\begin{array}{c}\text { Light } \\
\text { fast- } \\
\text { ness }\end{array}$ \\
\cline { 2 - 5 } & Fading & Staining & Dry & Wet & nodium \\
$\begin{array}{l}\text { Sodthionite } \\
\text { dite }\end{array}$ & 5 & 5 & 5 & 4 & 6 \\
\hline $\begin{array}{l}\text { Alkaline } \\
\text { protease }\end{array}$ & $4-5$ & $4-5$ & 5 & $4-5$ & 6 \\
\hline
\end{tabular}

\section{Conclusion}

The work presented in this study illustrates the use of alkaline protease, together with iron (II) sulphate, as a promising reducing agent for the dyeing of cotton with indigo. Both sodium dithionite $\left(\mathrm{Na}_{2} \mathrm{~S}_{2} \mathrm{O}_{4}\right)$ and alkaline protease demonstrated comparable K/S, with few variations. Dye strength with $3 \mathrm{~g} / \mathrm{l}$ indigo in the sodium dithionite system was a complete match with that of cotton dyed in the protease system for an indigo concentration of $7.5 \mathrm{~g} / \mathrm{l}$, although dye uptake with an increased concentration of indigo was found to be on the higher side. The stored baths in both the absence and presence of indigo showed good stability for up to 24 hours. However, the maximum dye strength was obtained at 0 hours of dyeing, i.e. just after the reduction and solubilisation of the dye. Damage on the surface of dyed cotton was less prominent in the alkaline protease-based reduction system. The change in the crystallinity index was around $4 \%$, meaning no significant damage was observed. The drop in the tensile strength of dyed cotton using alkaline protease was less significant than that using dithionite, as less damage to the cotton occurred. The colourfastness of dyed cotton was similar in both reduction systems. Thus, alkaline protease, together with iron (II) salt, could serve as a substitute for sodium dithionite.

\section{References}

1. ROESSLER, Albert, JIN, Xiunan. State of the art technologies and new electrochemical methods for the reduction of vat dyes. Dyes and Pigments, 2003, 59(3), 223-235, doi: 10.1016/S0143-7208(03)00108-6.

2. NAIR, G. P., TRIVEDI, S. S. Sodium sulphide in vat dyeing. Colourage, 1970, 17(27), 19-24.

3. SEMET, B., SACKINGEN, B., GURNINGER, G. E. Iron (II) salt complexes as alternatives to dithionite in vat dyeing. Melliand Textilberichte, 199, 76(3), 161-64.

4. ROESSLER, Albert, DOSSENBACH, Otmar, MARTE, Walter, RYS, Paul. Electrocatalytic hydrogenation of vat dyes. Dyes and Pigments, 2002, 54(2), 141-146, doi: 10.1016/S0143-7208(02)00035-9.

5. ROESSLER, Albert, CRETTENAND, David. Direct electrochemical reduction of vat dyes in a fixed bed of graphite granules. Dyes and Pigments, 2004, 63(1), 29-37, doi: 10.1016/j.dyepig.2004.01.005.

6. CHAVAN, R. B., CHAKRABORTY, J. N. Dyeing of cotton with indigo using iron(II) salt complexes. Coloration Technology. 2001, 117(2), 88-94, doi: 10.1111/j.1478-4408.2001.tb00340.x.

7. CHAKRABORTY, J.N., CHAVAN, R.B. Dyeing of cotton with vat dyes. AATCC Review, 2004, 4(7), 17-20.

8. CHAKRABORTY, J.N., DAS, M., CHAVAN, R.B. Kinetics of dyeing and properties of iron(II) salt complexes for reduction of vat dyes. Melliand International, 2005, 12(4), 319-323.

9. Textile processing with enzymes. Edited by A. Cavaco-Paulo and G. M. Gübitz. Cambridge : Woodhead Publishing, 2003, pp. 96-97.

10. Advances in textile biotechnology. Edited by V. Nierstrasz and A. Cavaco-Paulo. Cambridge : Woodhead Publishing, 2010, pp.15-18.

11. BOŽIČ, Mojca, PRICELIUS, Sina, GUEBITZ, George M., KOKOL, Vanja. Enzymatic reduction of complex redox dyes using NADH-dependent reductase from Bacillus subtilis coupled with cofactor regeneration. Applied Microbiology and Biotechnology, 2010, 85(3), 563-571, doi: 10. 1007/s00253-009-2164-8.

12. CHAKRABORTY, J. N., JARUHAR, Priyadarshi. Dyeing of cotton with sulphur dyes using alkaline catalase as reduction catalyst. Indian Journal of Fibre and Textile Research, 2014, 39(3), 303-309.

13. Technical report. Enzyme nomenclature. Amsterdam : Elsevier, 1973.

14. CASIDA, L. E. Jr. Industrial microbiology. New Delhi: New Age International Private Ltd, 1968 (reprint 2007), pp.390-401.

15. Chemical finishing of textiles. Edited by Wolfgang D. Schidler and Peter J. Hauser. Boca Raton [etc.] : CRC ; Cambridge, England : Woodhead, 2004, pp.181-186.

16. KUCHEL; Philip. Schaum's outlines : biochemistry. New York [etc.] : McGraw-Hill, 1998, pp. 229-231. 
17. Technical bulletin. Maps Enzymes Limited, May 2010, pp.1-4.

18. SHANKAR, S., MORE, S. V., LAXMAN, R. Seeta. Recovery of silver from waste $\mathrm{x}$-ray film by alkaline protease from conidiobolus coronatus. Kathmandu University Journal of Science, Engineering and Technology. 2010, 6(1), 60-69, doi: 10.3126/kuset.v6i1.3311.

19. GULRAJANI, M. L., GUPTA, Shailja Vaidya, GUPTA, Abhilasha, SURI, Mona. Degumming of silk with different alkaline protease enzymes. Indian Journal of Fibre and Textil Research, 1996, 21, 270-275.

20. TELI, M. D., PAUL, Roshan, LANDAGE, Sachin M., AICH, Arnab. Ecofriendly processing of sulphur and vat dyes-An overview. ndian Journal of Fibre and Textil Research, 2001, 26, 101-107.

21. MISHRA, A., GOEL, A. Relationship between weight loss and amino-acid released in protein treatment of wool hair blended fabric. Colourage, 2008, 55, 49-53.

22. HASAN, Md. Mahabub, NABI, Farhatun, MAHMUD, Rezwan. Benefits of enzymatic process in textile wet processing. International Journal of Fiber and Textile Research, 2015, 5(2), 16-19.

23. BOZACI, Ebru. Investigation of biosurfactant usage in raw wool scouring by response surface methodology. Tekstil ve Konfeksiyon, 2017, 27(4), 382-392.

24. DENG, Aihua, JIE, Wu, ZHANG, Guoqiang, WEN, Tinngyi. Biochimie Molecular and structural characterization of a surfactant-stable high-alkaline protease AprB with a novel structural feature unique to subtilisin family. Biochimie, 2011, 93(4), 783-791, doi: 10.1016/j. biochi.2011.01.011.

25. TAIKHAO, Samrat, PHUNPRUCH, Saranya. Effect of metal cofactors of key enzymes on biohydrogen production by nitrogen fixing cyanobacterium anabaena siamensis TISIR 8012. Energy Procedia, 2017, 138, 360-5, doi: 10.1016/j. egypro.2017.10.166.

26. POSNER, Israel, MORALES, Alfredo. Mechanisms of enzyme and substrate activation by lipoprotein lipase cofactors. The Journal of Biological Chemistry, 1972, 247(8), 2255-2265.

27. LEE, Sujeong, KIM, Youn Joong, MOON, HiSoo.S. Energy-filtering transmission electron microscopy (EF-TEM) study of a modulated struc- ture in metakaolinite, represented by a $14 \AA$ modulation. Journal of American Ceramic Society, 2003, 86(1), 174-6, doi: 10.1111/j.1151-2916.2003. tb03297.x.

28. POPESCU, Maria-Cristina, POPESCU, Carmen-Mihaela, LISA, Gabriela, SAKATA, Yusaku. Evaluation of morphological and chemical aspects of different wood species by spectroscopy and thermal methods. Journal of Molecular Structure, 2011, 988(1-3), 65-72, doi: 10.1016/j.molstruc.2010.12.004.

29. ROSA, M. F., MEDEIROS, E. S., MALMONGE, J. A., GREGORSKI, K. S., WOOD, D. F., MATTOSO, L. H. C., GLENN, G., ORTS, W. J., IMAM, S. H. Cellulose nanowhiskers from coconut husk fibers: Effect of preparation conditions on their thermal and morphological behavior. Carbohydrate Polymers, 2010, 81(1), 83-92, doi: 10.1016/j.carbpol.2010.01.059.

30. POLETTO, Matheus, ORNAGHI, Heitor, ZATTERA, Ademir. Native cellulose: Structure, characterization and thermal properties. Materials, 2014, 7(9), 6105-6119, doi: 0.3390/ma7096105.

31. SILVERSTEIN, Robert, M., WEBSTER, Francis, X., KIEMLE, David, J. Spectrometric identification of organic compound. Seventh edition. Haboken : John Wiley \& Sons, 2005, pp. 502.

32. POLETTO, Matheus, PISTOR, Vinícius, ZENI, Mara, ZATTERA, Ademir J. Crystalline properties and decomposition kinetics of cellulose fibers in wood pulp obtained by two pulping processes. Polymer Degradation and Stability, 2011, 96(4), 679685, doi: 10.1016/j.polymdegradstab.2010.12.007.

33. YOKOI, Hiroaki, NAKASE, Takahito, GOTO, Kuniyoshi, ISHIDA, Yasuyuki, OHTANI, Hajime, TSUGE, Shin, SONODA, Tetsuya, ONA, Toshihiro. Rapid characterization of wood extractives in wood by thermal desorption-gas chromatography in the presence of tetramethylammonium acetate. Journal of Analytical and Applied Pyrolysis, 2003, 67(1), 191-200 doi: 10.1016/s0165-2370(02)00061-x.

34. BARAN, Anna, FIEDLER, Andrea, SCHULZ, Hartwig, BARANSKA, Malgorzata. In situ Raman and IR spectroscopic analysis of indigo dye. Anal Methods, 2010, 2(9), 1372-1376, doi: 10.1039/c0ay00311e.

35. WADA, Masahisa, OKANO, Takeshi. Localization of $\mathrm{I} \alpha$ and $\mathrm{I} \beta$ phases in algal cellulose revealed by acid treatments. Cellulose, 2001, 8(3), 183-188 